\title{
Evaluation of the Bioenergy Potential of Temer Musa: An Invasive Tree from the African Desert
}

\author{
Nikdalila Radenahmad, ${ }^{1}$ Md Sumon Reza ${ }^{10},{ }^{1}$ Muhammad Saifullah Abu Bakar, \\ Shahriar Shams, ${ }^{2}$ Alem Tesfai, ${ }^{3}$ Juntakan Taweekun, ${ }^{4}$ Nima Khalilpoor ${ }^{D},{ }^{5}$ \\ Abul Kalam Azad ${ }^{D},{ }^{1}$ and Alibek Issakhov ${ }^{6}$ \\ ${ }^{1}$ Faculty of Integrated Technologies, Universiti Brunei Darussalam, Jalan Tungku Link, Gadong BE 1410, \\ Bandar Seri Begawan, Brunei Darussalam \\ ${ }^{2}$ Faculty of Engineering, Universiti Teknologi Brunei, Jalan Tungku Link, Gadong BE 1410, \\ Bandar Seri Begawan, Brunei Darussalam \\ ${ }^{3}$ European Green Energy and Environment Consultancy Group (EGEEC), 119 Quadrant Court, Reading RG1 2GU, UK \\ ${ }^{4}$ Mechanical Engineering, Faculty of Engineering, Prince of Songkla University, Hatyai, Songkhla 90112, Thailand \\ ${ }^{5}$ Department of Energy Engineering, Graduate School of the Environment and Energy Science and Research Branch, \\ Islamic Azad University, Tehran, Iran \\ ${ }^{6}$ Faculty of Mechanics and Mathematics, Department of Mathematical and Computer Modelling, \\ Al-Farabi Kazakh National University, Almaty, Kazakhstan
}

Correspondence should be addressed to Nima Khalilpoor; nimakhalilpoor@gmail.com and Abul Kalam Azad; abul.azad@ ubd.edu.bn

Received 30 December 2020; Revised 10 March 2021; Accepted 19 March 2021; Published 1 April 2021

Academic Editor: Alireza Baghban

Copyright ( 2021 Nikdalila Radenahmad et al. This is an open access article distributed under the Creative Commons Attribution License, which permits unrestricted use, distribution, and reproduction in any medium, provided the original work is properly cited.

\begin{abstract}
Temer musa (Prosopis chilensis) is an invasive wild tree found in the desert of many countries, e.g., Eritrea, Ethiopia, Sudan, India, South Africa, and the USA. The thermochemical properties of this invasive tree were analyzed as a potential biomass feedstock for energy generation. The calorific value measurement of the temer musa wood was found to be $19.83 \mathrm{MJ} / \mathrm{kg}$. Thermogravimetric analysis and derivative weight profiles displayed that the decomposition happened in four stages representing moisture content, volatile matter, fixed carbon, and ash formation. The proximate parameters are in good range with other known biomasses and are found suitable for the thermochemical energy conversion. The gasification process confirmed the existence of several gases that are usually observed in invasive biomasses. All gasification gases were in the acceptable range, and no hydrogen sulfide gas was observed, which makes the conversion as environment friendly. The obtained results show that the energy conversion of temer musa is suitable for real-time implementation.
\end{abstract}

\section{Introduction}

Biomass is an attractive renewable energy source; it constitutes the biological matter obtained from living things and is possible to regrow [1-3]. Wood from the tropical/arid area is expected to have a high calorific value $(\mathrm{CV})$ as those trees are more heat tolerant from nature [3]. Therefore, the conversion of these trees to energy is economically viable. Direct combustion, gasification, and pyrolysis are the leading technologies for the thermochemical conversion of dried biomass to energy $[2,4]$. Gasification is in focus because it can transform various types of feedstock (biomass, coal, and biological wastes) into electrical energy through the syngas-powered generator, especially by the integration of biomass gasification and solid oxide fuel cell- (SOFC-) based combined and heat power generation (CHP) [5-7]. Temer musa is an invasive tree that has not been studied before for the energy generation prospect. 
Temer musa is an invasive tree, mainly found in the desert of different countries in Africa (e.g., Eritrea, Cameroon, Chad, Gambia, Ghana, Guinea, Nigeria, and South Africa), India, and the United States of America. It is a fastgrowing, abundant, and invasive tree species with a small to medium-sized tree normally about $12 \mathrm{~m}$ in height and $1 \mathrm{~m}$ in diameter. Due to its nature of fast-growing, this tree is very prospective and beneficial as a feedstock for energy generation. Temer musa belongs to the Fabaceae family and has different names in different parts of the world with scientific name of Prosopis chilensis. This tree is very harmful to the environment because it is producing huge carbon dioxide $\left(\mathrm{CO}_{2}\right)$, creating small amount of oxygen $\left(\mathrm{O}_{2}\right)$, and consuming massive amount of underground water [8]. According to the Pacific Islands Ecosystems at Risk (PIER), the risk score for the Prosopis chilensis is 19, which is very high in comparison to the international standard (the risk factor should be below 6) [9].

To protect the land, environment, and ecosystem from the adverse effect of this invasive species, biofuel technology is a new process to manage invasiveness by converting them into bioenergy $[10,11]$. Potential biomass gasification applications will help to protect the environment and solve energy problems in those countries [12]. Recently, intensive research interest has been grown to integrate biomass gasification systems with fuel cells to get higher efficiency where syngas from gasifiers can be the input fuel for the fuel cells [13-15]. Gasifiers are fed with a combustible material to produce syngas, hydrogen, or hydrogen-rich fuel, e.g., methane. These gases can be utilized as fuels to fuel the fuel cell $[16,17]$. Solid oxide fuel cell is a fuel cell category that allows various fuels, e.g., natural gas and hydrocarbons [18-20].

To utilize temer musa as a feedstock for real-time implementation, there exist challenges to concern in terms of (i) the management of biomass: source, storage, transportation, and sizing of biomass for gasification, (ii) the optimization of operating parameters of the gasifier, (iii) cleaning units to meet the gas purity requirement of solid oxide fuel cell and other units, (iv) solid oxide fuel cell materials development to cope with $\mathrm{H}_{2} \mathrm{~S}$ and carbon-containing syngas, and (v) application of electricity and heat from solid oxide fuel cell-based combined and heat power to a household. To the best of the authors' knowledge, no research has been performed to characterize temer musa for the potential application in power generation. Hence, this study aims to present the physical and chemical characterizations of the invasive temer musa as a potential feedstock for biomass gasification which can be used for powering syngas solid oxide fuel cell-based combined and the heat power system.

\section{Materials and Methods}

Temer musa branches were collected from Eritrea and cut into small pieces for drying under direct sunlight for one week. After sundry, the pieces were dried in oven at $100^{\circ} \mathrm{C}$ for overnight to remove the left moisture. Finally, the small pieces were ground into a powder and sieved by standard sieve no 60 to obtain $0.250 \mathrm{~mm}$ of biomass samples. The physical appearance, uprooting process, and available areas are shown in Figure 1.

2.1. Calorific Value (CV) Measurements. The biomass sample was pelletized to obtain a pellet of about $1 \mathrm{gm}$ for each experimental run. The pellet was placed in a bomb calorimeter (C200, P.A. Hilton Ltd.) to measure the heat of reaction according to the American Society for Testing and Materials D2015 method. Cotton thread and nichrome wire were used to lead the fire to the sample in the ignition stage of the bomb calorimeter equipment. Calorific value at constant volume was calculated using the following equation [22].

$$
\mathrm{CV}=\frac{\varepsilon \times \theta-m_{c} \times q_{c}-m_{w} \times q_{w}}{m_{f}},
$$

where $\mathrm{CV}$ is the calorific value $(\mathrm{kJ} / \mathrm{kg}), \varepsilon$ is the heat equivalent of the bomb $(\mathrm{J} / \mathrm{K}), \theta$ is the effective temperature rise $(\mathrm{K}), m_{c}$ is the mass of cotton thread $(\mathrm{g}), q_{c}$ is the calorific value of cotton thread $(\mathrm{J} / \mathrm{g}), m_{w}$ is the mass of nichrome wire ( $\mathrm{g}), q_{w}$ is the calorific value of nichrome wire $(\mathrm{J} / \mathrm{g})$, and $m_{f}$ is the mass of fuel (biomass) (g).

2.2. Combustion and Proximate Analysis. Small pieces $(\sim 1 \mathrm{~g})$ of temer musa were combusted in a furnace at about $500^{\circ} \mathrm{C}$. The furnace temperature was increased from $25^{\circ} \mathrm{C}$ to $500^{\circ} \mathrm{C}$ with a rate of $10^{\circ} \mathrm{C} / \mathrm{minas}$, and most of the dioxins and dioxin-related compounds are formed below $500^{\circ} \mathrm{C}$ temperature in the combustion zone [23]. Three gas sensors of Dräger X-am 5000 (sensor A detecting nitric oxide (NO), ammonia $\left(\mathrm{NH}_{3}\right)$, carbon dioxide $\left(\mathrm{CO}_{2}\right)$; sensor B detecting phosphine $\left(\mathrm{PH}_{3}\right)$, sulfur dioxide $\left(\mathrm{SO}_{2}\right)$, hydrogen sulfide $\left(\mathrm{H}_{2} \mathrm{~S}\right)$, and carbon monoxide $(\mathrm{CO})$; sensor $\mathrm{C}$ detecting nitrogen dioxide $\left(\mathrm{NO}_{2}\right)$, hydrogen cyanide $(\mathrm{HCN})$, and chlorine $\left(\mathrm{Cl}_{2}\right)$ ) were used to measure the output gases simultaneously.

Figure 2(a) shows the locally made gas detection system using a chamber and detectors. The gas is produced from the combustion of biomass in a furnace, and the gas passes through the gas line which was connected to the chamber. The chamber can control the gas dispersion for data collection. The data of gases produced were collected from sensor monitors every 5 minutes after starting biomass combustion to study the exhaust gas. Proximate analysis is an important characteristic to estimate the suitability of biomass material for thermochemical conversion. In the analysis, moisture content (MC), volatile matter (VM), fixed carbon (FC), and ash content (AC) were obtained by the simultaneous thermal analyzer, STA8000, Perkin Elmer at Prince of Songkla University by using the American Society for Testing and Materials E1131 [24] method. This method efficiently performs the compositional analysis (volatile matter, combustible materials, and ash content) of solid and liquid. Nitrogen was introduced to the sample from ambient to $600^{\circ} \mathrm{C}$, and the air was fed to the sample from $600^{\circ} \mathrm{C}$ until 


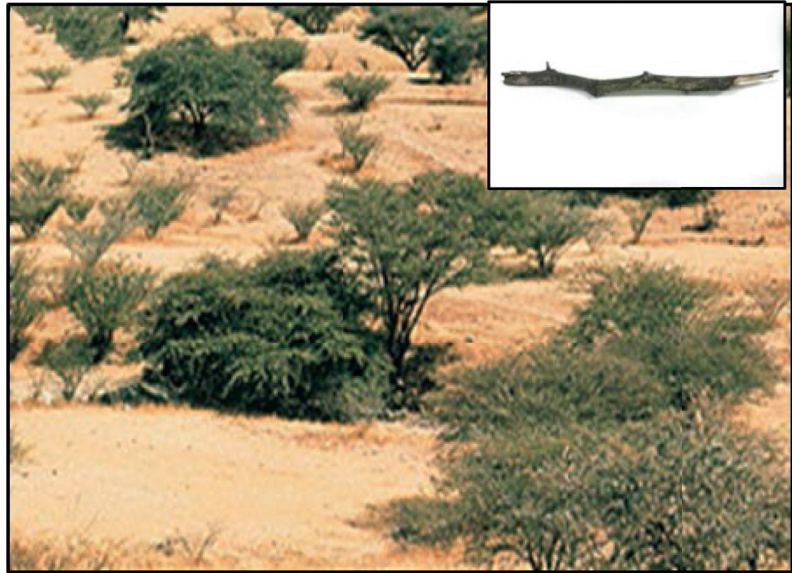

(a)

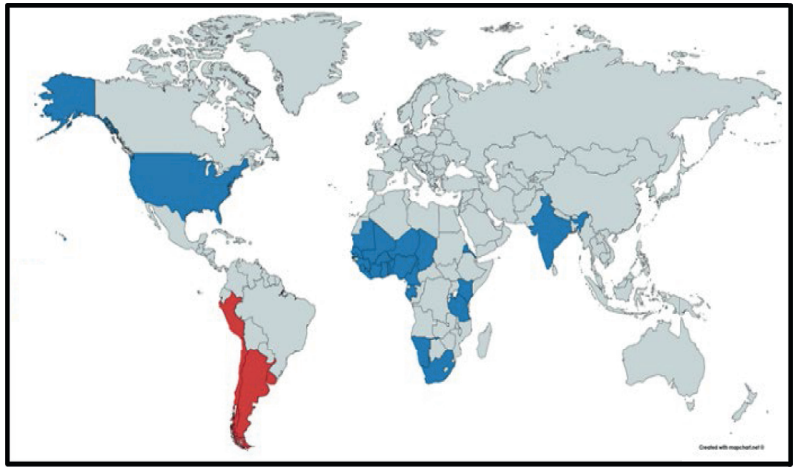

Native range

Exotic range

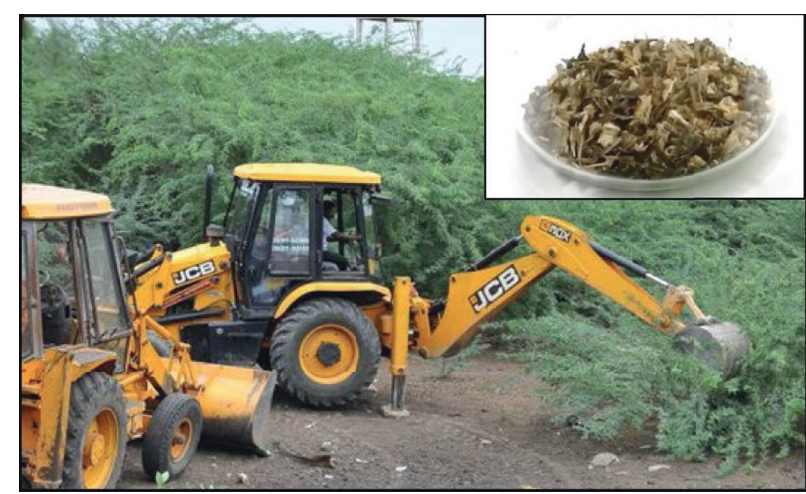

(b)

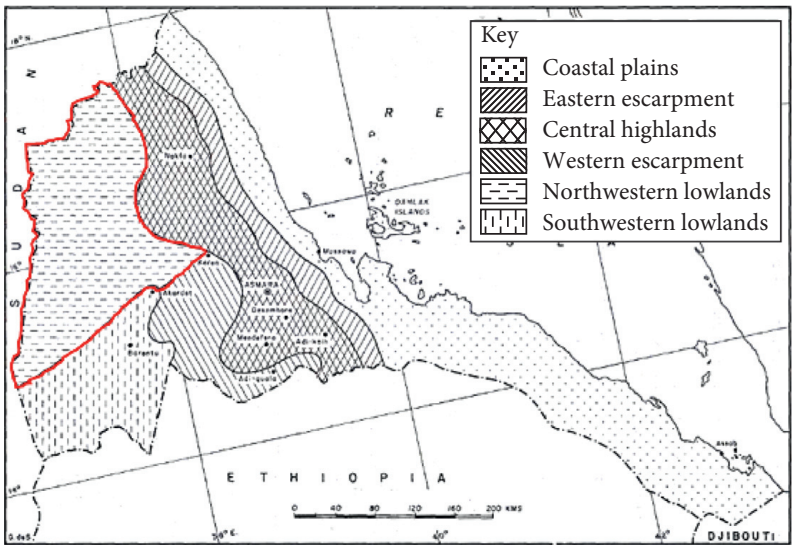

(d)

Figure 1: Picture of (a) temer musa tree, (b) uprooting process, (c) the map of countries where the species are available, and (d) the main agroclimatic zone of Eritrea where the trees are most available (highlighted in red border) [21]. The wood branch of temer musa is shown in the inset of (a), and small pieces of original temer musa are shown in the inset of (b).

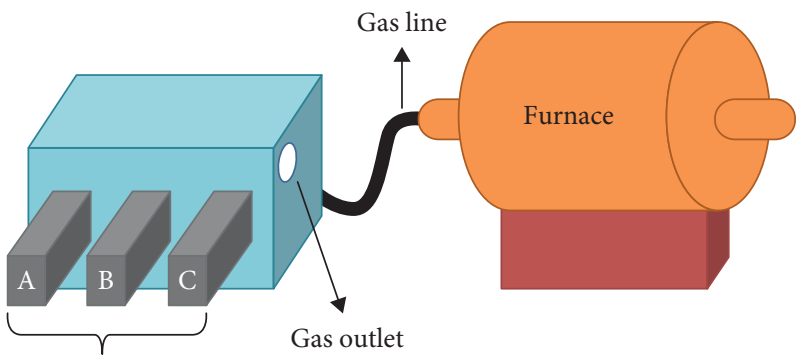

Gas sensors

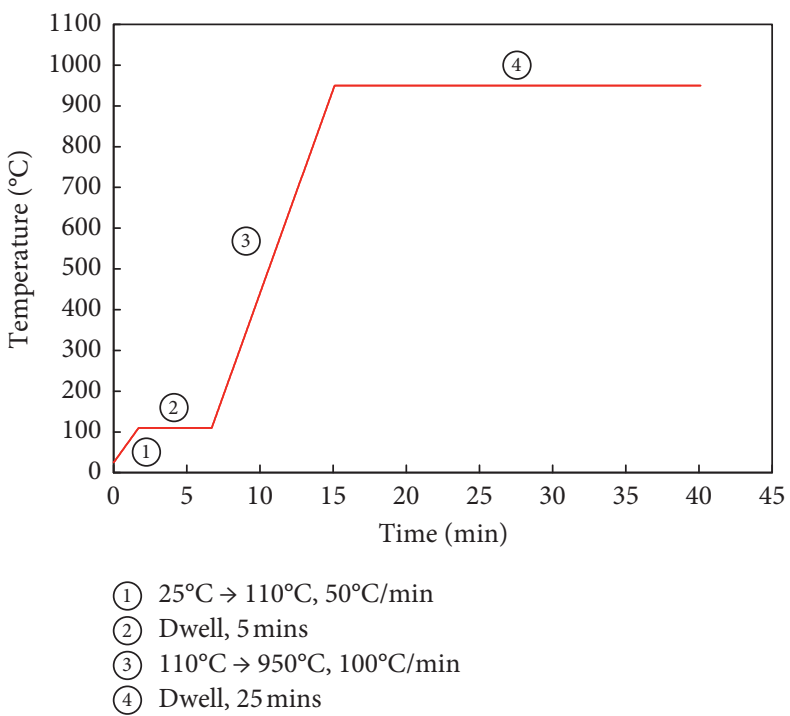

(b)

Figure 2: (a) Diagram of combustion gas analysis where gases were fed to a chamber fed into 3 different detectors placed to detect different gas. (b) Temperature versus time plot of thermogravimetric analysis profile of the sample from $25^{\circ} \mathrm{C}$ to $950^{\circ} \mathrm{C}$. 
$1000^{\circ} \mathrm{C}$. In the oxidizing atmosphere, fixed carbon is oxidized at $750^{\circ} \mathrm{C}$ while ash is the residue.

Proximate analysis examination based on the thermogravimetric analysis method is accurate with the reason that the initial mass was weighed when the system was in a steady state before the heat was introduced, and the thermal behavior profile started to display when temperature increases until $1000^{\circ} \mathrm{C}$. About $37.73 \mathrm{mg}$ of temer musa wood sample was placed in the thermogravimetric analysis equipment and heated in two steps with two dwell time settings, as shown in Figure 2(b). In the first step, the sample was heated from $25^{\circ} \mathrm{C}$ to $110^{\circ} \mathrm{C}$ at $50^{\circ} \mathrm{C} / \mathrm{min}$ and dwelled at $110^{\circ} \mathrm{C}$ for 5 minutes. In the second step, the temperature was raised from $110^{\circ} \mathrm{C}$ to $950^{\circ} \mathrm{C}$ at $100^{\circ} \mathrm{C} / \mathrm{min}$ and resided for 25 minutes.

\section{Result and Discussion}

3.1. Calorific Value (CV) Experiment. Calorific value (CV) is a significant method for justifying the biomass as a potential source of energy [25]. This value is influenced by chemical composition, moisture, and ash content. The average gross calorific value (GCV) or high heating value (HHV) of temer musa was achieved by $19.83 \mathrm{MJ} / \mathrm{kg}$ on the dry basis and $17.93 \mathrm{MJ} / \mathrm{kg}$ on the wet basis. The standard deviations on a dry and wet basis are 0.3801 and 0.3436 , respectively. Gross calorific value is the energy released from an oven-dry material, while the net calorific value (NCV) is from an airdry material [26]. The calorific value of oven-dried wood samples was reported in the literature as in the range $17-20 \mathrm{MJ} / \mathrm{kg}$ [27]. The calorific values from experiments are in good agreement with the values from the literature and even highest compared to the existed results. This indicated the heat energy contained in temer musa as a potential feedstock for energy conversion. The dry basis calorific value, $19.83 \mathrm{MJ} / \mathrm{kg}$, is compared with other biomass materials from different countries of Africa (Table 1) to evaluate that temer musa has a high heating value as in a comparable range to the literature. Although hardwoods have a higher calorific value than softwoods and vines, the ash content is also high, meaning that the calorific value is not the only factor to consider for the application of biomass. Several studies utilize biomass bottom ash as the alternate in the production of concrete and cement mortar, e.g., as a filler in road embankments, cement-treated materials, or nonstructural concrete, which rely on the substitution ratio. A recent report by Orwa et al. [32] showed that temer musa has a high calorific value with little ash. The high calorific value of biomass is an advantageous property to use as a feedstock in the thermochemical process. As temer musa has a high calorific value, the agreement with reported values of other wood types shows the capacity of heat energy produced. The high calorific value of this biomass has the indication that this invasive tree can be a candidate as a feedstock for thermochemical conversion in biomass gasification. Biomass gasification can gasify biomass into combustible gaseous products that can run the gas engine to generate electricity. Temer musa is a promising tree for future electrical energy resources.
3.2. Proximate Analysis. To evaluate the thermochemical reaction in the biomass during pyrolysis/gasification, thermogravimetric analysis (TGA) is one of the best methods to know mass loss through thermal degradation [34]. Thermogravimetric analysis, as shown in Figure 3(a), revealed the mass loss of temer musa with time at $25-950^{\circ} \mathrm{C}$. The main derivative weight peaks demonstrated the maximum thermal degradation rate of biomass at elevated temperatures. In the biomass degradation stages, each biomass component decomposes in a distinct temperature range. Figure 3(b) is shown as a comparison for the obtained thermogravimetric analysis profile and derivative weight of temer musa. The mass loss and derivative weight profiles are in good agreement with a report of wood-based material, which displayed the same trend of biomass degradation. The thermogravimetric analysis graph displayed three regions of mass change, while the main peaks of biomass degradation are observed from the derivative weight profile as three thermal degradation stages $[10,35]$. Table 2 gives the detail of the weight loss from the as-received sample and dry basis sample as a comparison. The first mass loss of $9.583 \%$ occurred from room temperature until $110^{\circ} \mathrm{C}$ has shown the removal of light volatile matter and moisture contents that are available in biomass $[36,37]$ with the peak of derivative weight at $110^{\circ} \mathrm{C}$ temperature. The moisture content for this invasive species is promising because if the moisture content percentage is more than $10 \%$, there are negative effects on the biofuel production during thermochemical conversion [38]. The weight change is comparable to that of Eucalyptus globulus, Eucalyptus saligna, and Eucalyptus grandis, which are in the range of 9.94-12\% [30]. A report revealed that the moisture content of Prosopis africana and Balanites aegyptiaca were $10 \%$ and $12 \%$, respectively [28]. The moisture content from this experiment was lower than the literature values. This showed a positive property and is the reason for the high calorific value of temer musa. The heat obtained from the combustion of biomass is influenced by the moisture content. If a sample contains moisture, for complete combustion, the heat needs to first remove the moisture, which decreases the total heat achieved [29]. High moisture content was found to reduce the combustion yield [39]. The second mass change began dramatically at $350^{\circ} \mathrm{C}$ until $750^{\circ} \mathrm{C}$, while mass was stable at $950^{\circ} \mathrm{C}$ where the peak of derivative weight happened at $500^{\circ} \mathrm{C}$ has shown the degradation point of volatile matter, which is in agreement with the normal volatilization range of $200-750^{\circ} \mathrm{C}$ in nitrogen $[9,10,40]$. The weight loss was at $74.98 \%$ between $110^{\circ} \mathrm{C}$ and $950^{\circ} \mathrm{C}$ mainly for the degradation of hemicellulose, cellulose, and lignin [9]. The steady mass at $950^{\circ} \mathrm{C}$ indicates that the total volatile matter was removed. However, volatile matters consist of combustible gases that facilitate the ignition stage, which is advantageous in the thermochemical conversion process. In the third region of weight change, the severe mass loss represents the fixed carbon level which is the nonvolatile matter, combustible, and oxidizable. Temer musa displayed the loss of fixed carbon content at $950^{\circ} \mathrm{C}$ under the oxygen atmosphere in the derivative weight curve. The loss of fixed carbon is caused by the carbonization process and lignin decomposition [41]. Proximate analysis of woods consists of 
TABLE 1: Comparison of the calorific value of different trees from different parts of Africa.

\begin{tabular}{lcc}
\hline Sample & Calorific value $(\mathrm{MJ} / \mathrm{kg})$ & Country of resources \\
\hline Temer musa & 19.83 & Eritrea \\
Prosopis africana & 19.80 & Niger and Burkina Faso \\
Balanites aegyptiaca & 19.40 & \\
Acacia cyclops & 18.99 & \\
Acacia erioloba & 19.03 & South African \\
Eucalyptus cladocalyx & 18.87 & \\
Pinus patula & 18.68 & \\
Vitis vinifera & 18.73 & Ethiopia \\
Eucalyptus globulus & $18.77-19.34\left(4486-4623 \mathrm{kcal}^{*} / \mathrm{kg}\right)$ & \\
Eucalyptus saligna & $18.98-19.24\left(4536-4599 \mathrm{kcal}^{*} / \mathrm{kg}\right)$ & \\
Eucalyptus grandis & $18.88-19.42\left(4513-4641 \mathrm{kcal}^{*} / \mathrm{kg}\right)$ & \\
Bauhinia rufescens & 19.40 & Niger \\
Azadirachta indica & 19.40 & \\
Acacia senegal & 18.90 & \\
Faidherbia albida & 18.90 & \\
Acacia nilotica & 18.60 & \\
\hline
\end{tabular}

${ }^{*} 1 \mathrm{kcal}=4184 \mathrm{~J}$.

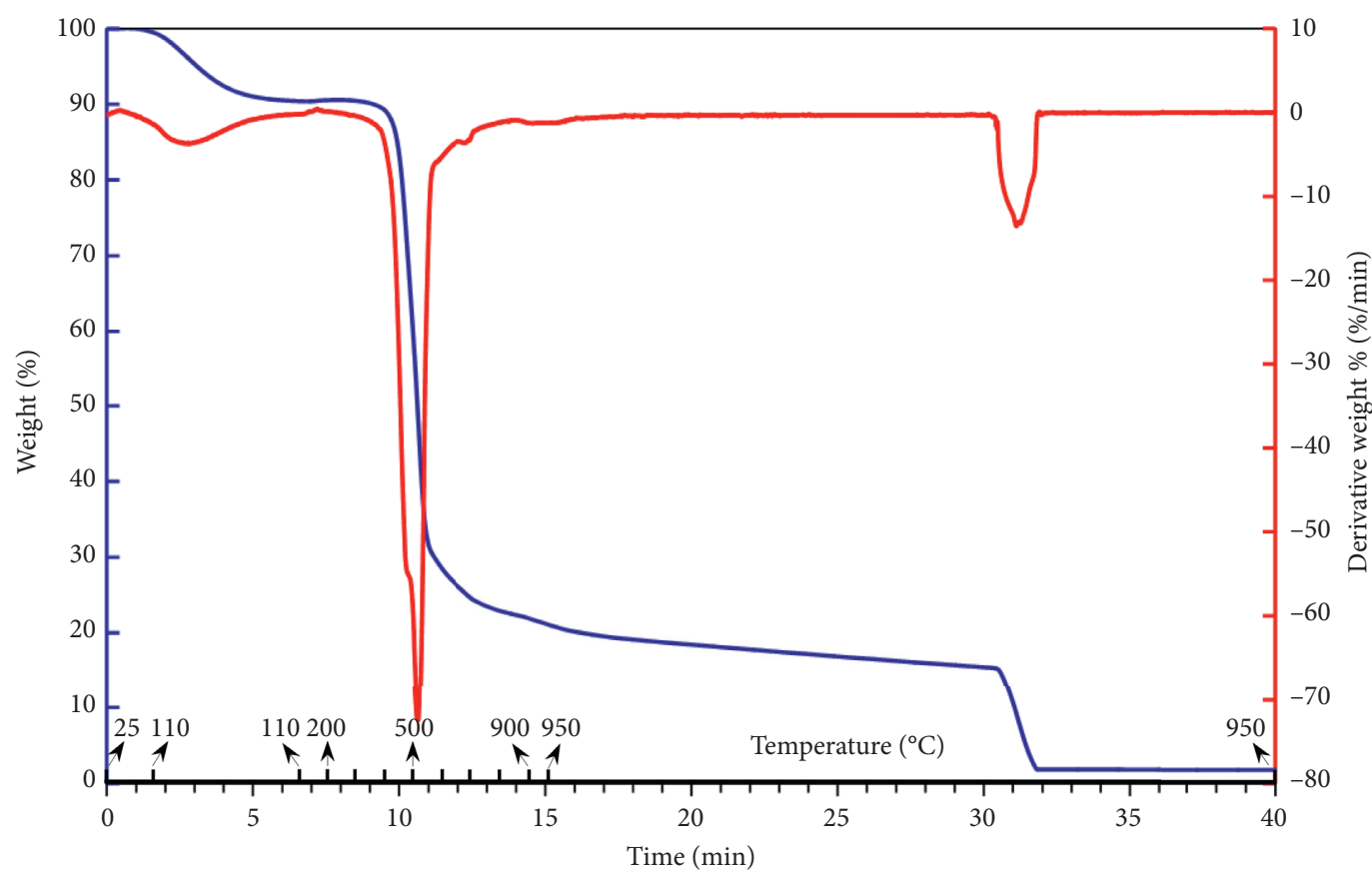

(a)

Figure 3: Continued. 

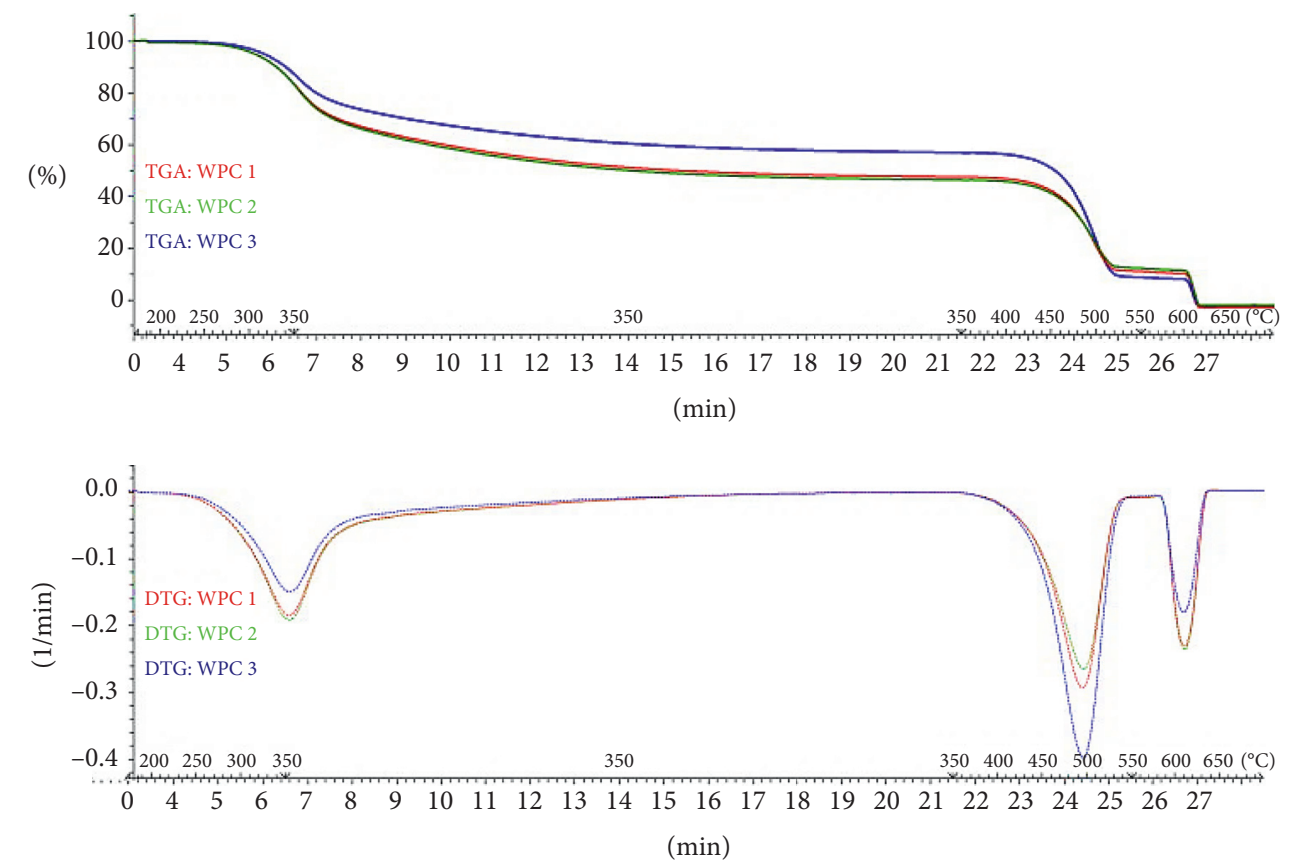

(b)

FIgURE 3: The thermogravimetric analysis profile and derivative weight of (a) temer musa with the three regions of weight changed and (b) wood-based material [33] for comparison.

TABLE 2: Proximate analysis results of temer musa branches.

\begin{tabular}{lccccc}
\hline Sample & Moisture & $\begin{array}{c}\text { Volatile } \\
\text { matter }\end{array}$ & $\begin{array}{c}\text { Fixed } \\
\text { carbon }\end{array}$ & Ash & Total \\
\hline $\begin{array}{l}\text { As received } \\
\begin{array}{l}\text { As dry } \\
\text { basis }\end{array}\end{array}$ & 9.583 & 74.98 & 13.59 & 1.848 & 100.0 \\
\hline
\end{tabular}

volatile matter (70.00-83.60\%), fixed carbon (15.20-28.30\%), and ash (0.10-11.30\%) [42]. A report described that a high ratio of volatile matter and fixed carbon has a relationship with the reactivity of the fuel [39]. The volatile matter given in Table 2 is in the range of $70-85 \%$, while fixed carbon is at a lower range of $10-15 \%$, indicating that the ratio of volatile matter by fixed carbon is high. This ratio is proved to enhance fuel ignition. At the last region of stable weight change, ash content remains as a nonvolatile residue in oxygen after complete volatilization [24]. Ash is an inorganic substance that is incombustible. At $950^{\circ} \mathrm{C}$, the remaining mass represents the ash content of $1.848 \%$, meaning that incombustible ash was present which is comparable to the literature range of $0.10-11.30 \%$. The lower ash content gives a higher calorific value [43]. Since biomass gasification consists of pyrolysis and combustion, the thermogravimetric analysis in nitrogen can represent the pyrolysis stage, and combustion thermal behavior can be observed from the thermogravimetric analysis in oxygen.

The biomass mainly consists of hemicellulose, cellulose, lignin, and small amounts of other organics [1]. Yang et al. revealed that hemicellulose is easy to remove from the main stem, which occurs in the range of $220-315^{\circ} \mathrm{C}$, while the structure of cellulose is very strong, which degrades in the range of $315-400^{\circ} \mathrm{C}$ [44]. The derivative weight peak of temer musa at $362^{\circ} \mathrm{C}$, which exists in a thermal degradation range of $220-400^{\circ} \mathrm{C}$, seems to cause hemicellulose and cellulose degradation. Lignin is the most difficult structure to decompose in which degradation happens slowly and constantly in a wide range of $150-900^{\circ} \mathrm{C}$ [9]. However, hemicellulose, cellulose, and lignin degradation can be observed in pyrolysis conditions [44]. The proximate analysis parameters are in the expected range compared with the literature. Less moisture content and ash were achieved, indicating the ability of energy generation when temer musa is used since less moisture increases the chance of energy derived from biomass. In addition, less ash content in biomass is advantageous in the prevention of clogging when biomass gasification is applied [10]. However, the capacity and efficiency of biomass gasification integrated solid oxide fuel cell-based combined heat and power can be examined to implement the approach with a novel feedstock, temer musa.

3.3. Combustion Gas Analysis. A combustion gas analysis was carried out in the closed system to evaluate the gas produced and to observe the safety of the experiment from the combustion of temer musa in the lack of air which can represent the gas produced in the combustion stage when real-time biomass gasification is used.

As given in Table 3, $\mathrm{NO}, \mathrm{NH}_{3}, \mathrm{PH}_{3}, \mathrm{SO}_{2}, \mathrm{CO}, \mathrm{NO}_{2}$, and $\mathrm{Cl}_{2}$ were detected from gas sensors, while $\mathrm{H}_{2} \mathrm{~S}$ was not found, which is good for the environment [45]. Most gases were found at the temperature above $414^{\circ} \mathrm{C}$, while $\mathrm{NO}_{2}$ and $\mathrm{Cl}_{2}$ 
TABLE 3: Gas detected from the combustion of temer musa by gas sensors.

\begin{tabular}{|c|c|c|c|c|}
\hline \multirow{2}{*}{ Gas (ppm/vol\%*) } & \multicolumn{4}{|c|}{ Content by temperature } \\
\hline & $25-364^{\circ} \mathrm{C}$ & $414^{\circ} \mathrm{C}$ & $465^{\circ} \mathrm{C}$ & $502^{\circ} \mathrm{C}$ \\
\hline $\mathrm{NO}$ & 0.00 & 0.50 & 0.00 & 0.90 \\
\hline $\mathrm{NH}_{3}$ & 0.00 & 13.0 & 8.00 & 13.0 \\
\hline $\mathrm{CO}_{2}$ & 0.00 & 0.00 & 0.00 & 0.00 \\
\hline $\mathrm{PH}_{3}$ & 0.00 & 0.33 & 0.18 & 0.49 \\
\hline $\mathrm{SO}_{2}$ & 0.00 & 1.80 & 1.00 & 2.80 \\
\hline $\mathrm{H}_{2} \mathrm{~S}$ & 0.00 & 0.00 & 0.00 & 0.00 \\
\hline $\mathrm{CO}$ & 0.00 & 48.0 & 40.0 & 60.0 \\
\hline $\mathrm{NO}_{2}$ & 0.00 & 0.00 & 0.00 & 0.00 \\
\hline $\mathrm{HCN}$ & 0.00 & 1.00 & 0.60 & 1.20 \\
\hline $\mathrm{Cl}_{2}$ & 0.60 & 0.60 & 0.60 & 0.60 \\
\hline
\end{tabular}

*The unit of $\mathrm{CO}_{2}$.

TABLE 4: The standard immediately dangerous to life or health concentrations (IDLH) and exposure limits [48] of gases detected in experiments.

\begin{tabular}{|c|c|c|}
\hline Gas & IDLH & Exposure limits \\
\hline NO & $\begin{array}{c}100 \mathrm{ppm} \\
\left(1 \mathrm{ppm}=1.23 \mathrm{mg} / \mathrm{m}^{3}\right)\end{array}$ & $\begin{array}{l}\text { NIOSH REL: TWA } 25 \mathrm{ppm}\left(30 \mathrm{mg} / \mathrm{m}^{3}\right) \\
\text { OSHA PEL: TWA } 25 \mathrm{ppm}\left(30 \mathrm{mg} / \mathrm{m}^{3}\right)\end{array}$ \\
\hline $\mathrm{NH}_{3}$ & $\begin{array}{c}300 \mathrm{ppm} \\
\left(1 \mathrm{ppm}=0.70 \mathrm{mg} / \mathrm{m}^{3}\right)\end{array}$ & $\begin{array}{l}\text { NIOSH REL: TWA } 25 \mathrm{ppm}\left(18 \mathrm{mg} / \mathrm{m}^{3}\right) \\
\text { ST } 35 \mathrm{ppm}\left(27 \mathrm{mg} / \mathrm{m}^{3}\right) \\
\text { OSHA PEL } \dagger \text { : TWA } 50 \mathrm{ppm}\left(35 \mathrm{mg} / \mathrm{m}^{3}\right)\end{array}$ \\
\hline $\mathrm{CO}_{2}$ & $\begin{array}{c}40,000 \mathrm{ppm} \\
\left(1 \mathrm{ppm}=1.80 \mathrm{mg} / \mathrm{m}^{3}\right)\end{array}$ & $\begin{array}{l}\text { NIOSH REL: TWA } 5000 \mathrm{ppm}\left(9000 \mathrm{mg} / \mathrm{m}^{3}\right) \\
\text { ST 30,000 ppm }\left(54,000 \mathrm{mg} / \mathrm{m}^{3}\right) \\
\text { OSHA PEL†: TWA } 5000 \mathrm{ppm}\left(9000 \mathrm{mg} / \mathrm{m}^{3}\right)\end{array}$ \\
\hline $\mathrm{PH}_{3}$ & $\begin{array}{c}50 \mathrm{ppm} \\
\left(1 \mathrm{ppm}=1.39 \mathrm{mg} / \mathrm{m}^{3}\right)\end{array}$ & $\begin{array}{c}\text { NIOSH REL: TWA } 0.3 \mathrm{ppm}\left(0.4 \mathrm{mg} / \mathrm{m}^{3}\right) \\
\text { ST } 1 \mathrm{ppm}\left(1 \mathrm{mg} / \mathrm{m}^{3}\right) \\
\text { OSHA PEL } \uparrow \text { TWA } 0.3 \mathrm{ppm}\left(0.4 \mathrm{mg} / \mathrm{m}^{3}\right)\end{array}$ \\
\hline $\mathrm{SO}_{2}$ & $\begin{array}{c}100 \mathrm{ppm} \\
\left(1 \mathrm{ppm}=2.62 \mathrm{mg} / \mathrm{m}^{3}\right)\end{array}$ & $\begin{array}{c}\text { NIOSH REL: TWA } 2 \mathrm{ppm}\left(5 \mathrm{mg} / \mathrm{m}^{3}\right) \\
\text { ST } 5 \mathrm{ppm}\left(13 \mathrm{mg} / \mathrm{m}^{3}\right) \\
\text { OSHA PEL†: TWA } 5 \mathrm{ppm}\left(13 \mathrm{mg} / \mathrm{m}^{3}\right)\end{array}$ \\
\hline $\mathrm{H}_{2} \mathrm{~S}$ & $\begin{array}{c}100 \mathrm{ppm} \\
\left(1 \mathrm{ppm}=1.40 \mathrm{mg} / \mathrm{m}^{3}\right)\end{array}$ & $\begin{array}{c}\text { NIOSH REL: C } 10 \mathrm{ppm}\left(15 \mathrm{mg} / \mathrm{m}^{3}\right)[10 \text {-minute }] \\
\text { OSHA PEL } \uparrow: \text { C } 20 \mathrm{ppm} \\
50 \mathrm{ppm} \text { [10-minute maximum peak] }\end{array}$ \\
\hline $\mathrm{CO}$ & $\begin{array}{c}1200 \mathrm{ppm} \\
\left(1 \mathrm{ppm}=1.15 \mathrm{mg} / \mathrm{m}^{3}\right)\end{array}$ & $\begin{array}{c}\text { NIOSH REL: TWA } 35 \mathrm{ppm}\left(40 \mathrm{mg} / \mathrm{m}^{3}\right) \\
\text { C } 200 \mathrm{ppm}\left(229 \mathrm{mg} / \mathrm{m}^{3}\right) \\
\text { OSHA PEL } \dagger \text { : TWA } 50 \mathrm{ppm}\left(55 \mathrm{mg} / \mathrm{m}^{3}\right)\end{array}$ \\
\hline $\mathrm{NO}_{2}$ & $\begin{array}{c}20 \mathrm{ppm} \\
\left(1 \mathrm{ppm}=1.88 \mathrm{mg} / \mathrm{m}^{3}\right)\end{array}$ & $\begin{array}{l}\text { NIOSH REL: ST } 1 \mathrm{ppm}\left(1.8 \mathrm{mg} / \mathrm{m}^{3}\right) \\
\text { OSHA PEL } \dagger \text { : C } 5 \mathrm{ppm}\left(9 \mathrm{mg} / \mathrm{m}^{3}\right)\end{array}$ \\
\hline $\mathrm{HCN}$ & $\begin{array}{c}50 \mathrm{ppm} \\
\left(1 \mathrm{ppm}=1.10 \mathrm{mg} / \mathrm{m}^{3}\right)\end{array}$ & $\begin{array}{l}\text { NIOSH REL: ST } 4.7 \mathrm{ppm}\left(5 \mathrm{mg} / \mathrm{m}^{3}\right) \text { [skin] } \\
\text { OSHA PEL†: TWA } 10 \mathrm{ppm}\left(11 \mathrm{mg} / \mathrm{m}^{3}\right) \text { [skin] }\end{array}$ \\
\hline $\mathrm{Cl}_{2}$ & $\begin{array}{c}10 \mathrm{ppm} \\
\left(1 \mathrm{ppm}=2.90 \mathrm{mg} / \mathrm{m}^{3}\right)\end{array}$ & $\begin{array}{l}\text { NIOSH REL: C } 0.5 \mathrm{ppm}\left(1.45 \mathrm{mg} / \mathrm{m}^{3}\right)[15 \text {-minute }] \\
\text { OSHA PEL†: C } 1 \mathrm{ppm}\left(3 \mathrm{mg} / \mathrm{m}^{3}\right)\end{array}$ \\
\hline
\end{tabular}

were released at low temperature due to the higher releasing tendency of volatile matters [46]. The $\mathrm{CO}_{2}$ was not sensed even in limited gas dispersion in the chamber and with $1 \mathrm{~g}$ sample. On the other hand, HCN was detected at a temperature above $414^{\circ} \mathrm{C}$ indicating that the system is effective in the detection of $\mathrm{HCN}$ at elevated temperatures. At high temperatures, $\mathrm{PH}_{3}$ and $\mathrm{CO}$ were high in content as monitored by the sensors. In the experiments, the temperatures were not fixed, which is due to the data collection that took place every 5 minutes. The alarms (A1 and A2) are thresholds that appear when the content exceeds the set values of gas sensors [47]. At elevated temperatures, the gases were not at fixed values. This is because the gas sensors are designed for safety applications. However, an ultimate analysis is recommended to investigate the elemental gases of the biomass ( $, \mathrm{H}, \mathrm{O}, \mathrm{N}$, and $\mathrm{S}$ ). In addition, the gas chromatography technique can be used to analyze the syngas production from the thermochemical conversion of temer musa.

The standard Immediately Dangerous to Life or Health (IDLH) Concentrations and exposure limits to gases produced from combustion are given in Table 4. As a safety prospect, the combustion experiment can run 3-4 hours a week with the use of air circulation. This combustion experiment gave the estimation of gas content produced with temperature from biomass on a laboratory scale, which 
requires developing the gas controlling system or gas filtration in the future. As an example of NO produced (in Table 3) from the combustion of temer musa, the level of NO was $0.90 \mathrm{ppm}$ above $500^{\circ} \mathrm{C}$, which is lower than the exposure limit of $25 \mathrm{ppm}$ by inhalation for up to a 10-hour workday during a 40-hour workweek as stated where NIOSH REL is the National Institute for Occupational Safety and Health recommended exposure limits, TWA is a time-weighted average concentration for up to a 10-hour workday during a 40-hour workweek, OSHA PEL is the Occupational Safety and Health Administration permissible exposure limits, ST is a 15-minute TWA exposure that should not be exceeded at any time during a workday, $\mathrm{C}$ is a ceiling value that should not be exceeded at any time, and ${ }^{\dagger}$ is the end of service life indicator (ESLI) required. From the obtained data, the level of $0.90 \mathrm{ppm}$ is much lower than $100 \mathrm{ppm}$ in the standard Immediately Dangerous to Life or Health (IDHL) Concentrations, while other gases are correspondingly lower than IDHL [48].

\section{Conclusion}

The investigation of the physical and chemical properties of temer musa was carried out in this research. Temer musa showed a high calorific value of $19.83 \mathrm{MJ} / \mathrm{kg}$ on a dry basis, which is an important property of feedstock in thermochemical conversion. The thermogravimetric and proximate analyses revealed that the observed moisture content (9.583\%), ash content $(1.848 \%)$, volatile matter content (74.98\%), and fixed carbon (13.59\%) content can be advantageous in the thermochemical conversion process. A high ratio of volatile matter and fixed carbon has a relationship with the reactivity of the fuel in the enhancement of fuel ignition. The obtained proximate analysis values proved that this invasive biomass is an excellent source for the gasification conversion process. The gas combinations are the indications of the possibility, sustainability, and accessibility of temer musa as an effective source for the future energy generation process. So, these invasive temer musa trees can be a promising novel feedstock for biomass gasification integrated solid oxide fuel cell-based combined heat and power.

\section{Data Availability}

The data used to support the findings of this study are included within the article.

\section{Conflicts of Interest}

The authors declare that they have no conflicts of interest.

\section{Acknowledgments}

The author, NR, would like to thank Universiti Brunei Darussalam (UBD) for funding the UBD graduate scholarship to perform the research in the Faculty of Integrated Technologies, UBD. The authors are thankful to Environmental and Life Sciences, Faculty of Science, UBD, for assistance in the ball milling facility. This work was performed under Financial Assistance from a Competitive Research Grant (UBD/OVACRI/CRGWG(006)/161201).

\section{References}

[1] A. Ahmed, M. S. Abu Bakar, A. K. Azad, R. S. Sukri, and T. M. I. Mahlia, "Potential thermochemical conversion of bioenergy from Acacia species in Brunei Darussalam: a review," Renewable and Sustainable Energy Reviews, vol. 82, pp. 3060-3076, 2018.

[2] N. Radenahmad, A. T. Azad, M. Saghir et al., "A review on biomass derived syngas for SOFC based combined heat and power application," Renewable and Sustainable Energy Reviews, vol. 119, Article ID 109560, 2020.

[3] M. D. Madvar, A. Aslani, M. H. Ahmadi, and N. S. Karbalaie Ghomi, "Current status and future forecasting of biofuels technology development," International Journal of Energy Research, vol. 43, no. 3, pp. 1142-1160, 2019.

[4] P. McKendry, "Energy production from biomass (part 2): conversion technologies," Bioresource Technology, vol. 83, no. 1, pp. 47-54, 2002.

[5] S. Afroze, N. Torino, P. F. Henry, M. S. Reza, Q. Cheok, and A. K. Azad, "Neutron and X-ray powder diffraction data to determine the structural properties of novel layered perovskite $\mathrm{PrSrMn}_{2} \mathrm{O}_{5+\delta}$," Data in Brief, vol. 29, Article ID 105173, 2020.

[6] M. Beigzadeh, F. Pourfayaz, M. Ghazvini, and M. H. Ahmadi, "Energy and exergy analyses of solid oxide fuel cell-gas turbine hybrid systems fed by different renewable biofuels: a comparative study," Journal of Cleaner Production, vol. 280, Article ID 124383, 2021.

[7] M. Beigzadeh, F. Pourfayaz, and M. H. Ahmadi, "Modeling and improvement of solid oxide fuel cell-single effect absorption chiller hybrid system by using nanofluids as heat transporters," Applied Thermal Engineering, vol. 166, Article ID 114707, 2020.

[8] M. Dutta and J. Kumar Basu, "Application of response surface methodology for the removal of methylene blue by Acacia auriculiformis scrap wood char," Research Journal of Environmental Toxicology, vol. 5, no. 4, pp. 266-278, 2011.

[9] M. S. Reza, S. N. Islam, S. Afroze et al., "Evaluation of the bioenergy potential of invasive Pennisetum purpureum through pyrolysis and thermogravimetric analysis," Energy, Ecology and Environment, vol. 5, no. 2, pp. 118-133, 2020.

[10] M. S. Reza, A. Ahmed, W. Caesarendra et al., "Acacia holosericea: an invasive species for bio-char, bio-oil, and biogas production," Bioengineering, vol. 6, no. 2, p. 33, 2019.

[11] M. S. Reza, C. S. Yun, S. Afroze et al., "Preparation of activated carbon from biomass and its' applications in water and gas purification, a review," Arab Journal of Basic and Applied Sciences, vol. 27, no. 1, pp. 208-238, 2020.

[12] N. Radenahmad, M. S. Reza, M. S. A. Bakar, and A. K. Azad, "Thermochemical characterization of rice husk (Oryza sativa Linn) for power generation," ASEAN Journal of Chemical Engineering, vol. 20, no. 2, pp. 184-195, 2020.

[13] Z. Ud Din and Z. A. Zainal, "Biomass integrated gasificationSOFC systems: technology overview," Renewable and Sustainable Energy Reviews, vol. 53, pp. 1356-1376, 2016.

[14] N. Radenahmad, J. Taweekun, A. Afif, J.-Y. Park, J. Zaini, and A. K. Azad, "Syngas fuelled high performance solid oxide fuel cell," ECS Transactions, vol. 91, no. 1, pp. 1621-1629, 2019.

[15] M. Beigzadeh, F. Pourfayaz, and S. M. Pourkiaei, "Modeling heat and power generation for green buildings based on solid 
oxide fuel cells and renewable fuels (biogas)," Renewable Energy Research and Application, vol. 1, no. 1, pp. 55-63, 2020.

[16] S. Afroze, N. Torino, P. F. Henry, M. Sumon Reza, Q. Cheok, and A. K. Azad, "Insight of novel layered perovskite $\mathrm{PrSrMn}_{2} \mathrm{O}_{5+\delta}$ : A neutron powder diffraction study," Materials Letter, vol. 261, 2020.

[17] S. Afroze, N. Torino, M. S. Reza et al., "Structure-conductivity relationship of PrBaMnMoO6- $\delta$ through in-situ measurements: a neutron diffraction study," Ceramics International, vol. 47, no. 1, pp. 541-546, 2021.

[18] N. Radenahmad, A. Afif, P. I. Petra, S. M. H. Rahman, S.-G. Eriksson, and A. K. Azad, "Proton-conducting electrolytes for direct methanol and direct urea fuel cells-a stateof-the-art review," Renewable and Sustainable Energy Reviews, vol. 57, pp. 1347-1358, 2016.

[19] A. K. Azad, A. Kruth, and J. T. S. Irvine, "Influence of atmosphere on redox structure of $\mathrm{BaCe}_{0.9} \mathrm{Y}_{0.1} \mathrm{O}_{2.95}$-insight from neutron diffraction study," International Journal of Hydrogen Energy, vol. 39, no. 24, pp. 12804-12811, 2014.

[20] S. Afroze, H. Q. H. H. Absah, M. S. Reza et al., "Structural and electrochemical properties of lanthanum silicate apatites $\mathrm{La}_{10} \mathrm{Si}_{6-\mathrm{x}-0.2} \mathrm{Al}_{\mathrm{x}} \mathrm{Zn}_{0.2} \mathrm{O}_{27-\delta}$ for solid oxide fuel cells (SOFCs)," International Journal of Chemical Engineering, vol. 2021, Article ID 6621373, 10 pages, 2021.

[21] E. Bein, B. Habte, A. Jaber, A. Birnie, and B. Tengnas, Useful Trees and Shrubs in Eritrea, Regal Press Limited, London, UK, 1996.

[22] P.A. Hilton Ltd, Experimental Operating and Maintenance Manual-Bomb Calorimeter C200, P.A. Hilton Ltd, Stockbridge, UK, 2013.

[23] I. Horvat and D. Dović, "Combustion of agricultural biomassissues and solutions," Transactions of Famena, vol. 42, no. 1, pp. 75-86, 2018.

[24] ASTM International, Standard Test Method for Compositional Analysis by Thermogravimetry, ASTM International, West Conshohocken, PA, USA, 2012.

[25] J. M. Vargas-Moreno, A. J. Callejón-Ferre, J. Pérez-Alonso, and B. Velázquez-Martí, "A review of the mathematical models for predicting the heating value of biomass materials," Renewable and Sustainable Energy Reviews, vol. 16, no. 5, pp. 3065-3083, 2012.

[26] M. Erol, H. Haykiri-Acma, and S. Küçükbayrak, "Calorific value estimation of biomass from their proximate analyses data," Renewable Energy, vol. 35, no. 1, pp. 170-173, 2010.

[27] D. Fengel and G. Wegener, Wood Chemistry, Ultrastructre and Reactions, Walter de Gruyter, Berlin, Germany, 1983.

[28] C. S. Montes, D. A. De Silva, R. A. Garcia, J. C. Weber, and G. I. B. De Muniz, "Calorific value of Prosopis africana and Balanites aegyptiaca wood: relationships with tree growth, wood density and rainfall gradients in the West African Sahel," Biomass and Bioenergy, vol. 35, pp. 346-353, 2011.

[29] F. Munalula and M. Meincken, "An evaluation of South African fuelwood with regards to calorific value and environmental impact," Biomass and Bioenergy, vol. 33, 2009.

[30] M. Lemenih and T. Bekele, "Effect of age on calorific value and some mechanical properties of three Eucalyptus species grown in Ethiopia," Biomass and Bioenergy, vol. 27, no. 3, pp. 223-232, 2004.

[31] J. P. A. Lamers, K. Michels, and R. J. Vandenbeldt, "Trees and windbreaks in the Sahel: establishment, growth, nutritive, and calorific values," Agroforestry Systems, vol. 26, no. 3, pp. 171-184, 1994.

[32] C. Orwa, A. Mutua, R. Kindt, R. Jamnadass, and A. Simons, Prosopis Chilensis Agroforestry Database 4.0, World
Agroforestry Centre, Nairobi, Kenya, 2009, http:// worldagroforestry.org/output/agroforestree-database.

[33] H. Jeske, A. Schirp, and F. Cornelius, "Development of a thermogravimetric analysis (TGA) method for quantitative analysis of wood flour and polypropylene in wood plastic composites (WPC)," Thermochimica Acta, vol. 543, pp. 165171, 2012.

[34] A. I. Mabuda, N. S. Mamphweli, and E. L. Meyer, "Model free kinetic analysis of biomass/sorbent blends for gasification purposes," Renewable and Sustainable Energy Reviews, vol. 53, pp. 1656-1664, 2016.

[35] M. S. Reza, S. Afroze, M. S. A. Bakar et al., "Biochar characterization of invasive Pennisetum purpureum grass: effect of pyrolysis temperature," Biochar, vol. 2, no. 2, pp. 239-251, 2020.

[36] J. C. G. da Silva, J. L. F. Alves, W. V. de Araujo Galdino, R. F. de Sena, and S. L. F. Andersen, "Pyrolysis kinetics and physicochemical characteristics of skin, husk, and shell from green coconut wastes," Energy, Ecology and Environment, vol. 4, no. 3, pp. 125-132, 2019.

[37] M. S. Reza, S. N. Islam, S. Afroze, M. S. A. Bakar, J. Taweekun, and A. K. Azad, "Data on FTIR, TGA-DTG, DSC of invasive Pennisetum purpureum grass," Data in Brief, vol. 30, Article ID 105536, 2020.

[38] K. L. Kenney, W. A. Smith, G. L. Gresham, and T. L. Westover, "Understanding biomass feedstock variability,” Biofuels, vol. 4, no. 1, pp. 111-127, 2013.

[39] R. García, C. Pizarro, A. G. Lavín, and J. L. Bueno, "Biomass proximate analysis using thermogravimetry," Bioresource Technology, vol. 139, pp. 1-4, 2013.

[40] M. S. Reza, S. Afro, A. K. Azad et al., "Thermochemical characterization of invasive Axonopus compressus grass as a renewable energy source," in Proceedings of the 5th International Conference of Chemical Engineering and Industrial Biotechnology (ICCEIB 2020), pp. 1-6, Kuala Lumpur, Malaysia, August 2020.

[41] D. Kalderis, S. Bethanis, P. Paraskeva, and E. Diamadopoulos, "Production of activated carbon from bagasse and rice husk by a single-stage chemical activation method at low retention times," Bioresource Technology, vol. 99, no. 15, pp. 6809-6816, 2008.

[42] H. Uzun, Z. Yıldız, J. L. Goldfarb, and S. Ceylan, "Improved prediction of higher heating value of biomass using an artificial neural network model based on proximate analysis," Bioresource Technology, vol. 234, pp. 122-130, 2017.

[43] G. D. Gillespie, C. D. Everard, C. C. Fagan, and K. P. McDonnell, "Prediction of quality parameters of biomass pellets from proximate and ultimate analysis," Fuel, vol. 111, pp. 771-777, 2013.

[44] H. Yang, R. Yan, H. Chen, D. H. Lee, and C. Zheng, "Characteristics of hemicellulose, cellulose and lignin pyrolysis," Fuel, vol. 86, no. 12-13, pp. 1781-1788, 2007.

[45] J. Kazmierczak-Razna, B. Gralak-Podemska, P. Nowicki, and R. Pietrzak, "The use of microwave radiation for obtaining activated carbons from sawdust and their potential application in removal of $\mathrm{NO}_{2}$ and $\mathrm{H}_{2} \mathrm{~S}$," Chemical Engineering Journal, vol. 269, pp. 352-358, 2015.

[46] G. Chen, J. Li, K. Li et al., "Nitrogen, sulfur, chlorine containing pollutants releasing characteristics during pyrolysis and combustion of oily sludge," Fuel, vol. 273, Article ID 117772, 2020.

[47] Dräger Safety AG \& Co. KGaA, DrägerSensor ${ }^{\circledR}$ \& Portable Instruments Handbook, Dräger Safety AG \& Co. KGaA, Lubeck, Germany, 2016. 
[48] C.Department of Health and Human Service, NIOSH Pocket Guide to Chemical Hazards, NIOSH Publications, Cincinnati, OH, USA, 2007. 